AperTO - Archivio Istituzionale Open Access dell'Università di Torino

\title{
Who is the Author of Halakhah?
}

\section{This is the author's manuscript}

Original Citation:

Availability:

This version is available http://hdl.handle.net/2318/31196

since 2016-06-11T17:39:20Z

Published version:

DOI:10.1007/s11196-012-9268-7

Terms of use:

Open Access

Anyone can freely access the full text of works made available as "Open Access". Works made available under a Creative Commons license can be used according to the terms and conditions of said license. Use of all other works requires consent of the right holder (author or publisher) if not exempted from copyright protection by the applicable law. 
Dear Author,

\section{Springer}

Here are the proofs of your article.

- You can submit your corrections online, via e-mail or by fax.

- For online submission please insert your corrections in the online correction form. Always indicate the line number to which the correction refers.

- You can also insert your corrections in the proof PDF and email the annotated PDF.

- For fax submission, please ensure that your corrections are clearly legible. Use a fine black pen and write the correction in the margin, not too close to the edge of the page.

- Remember to note the journal title, article number, and your name when sending your response via e-mail or fax.

- Check the metadata sheet to make sure that the header information, especially author names and the corresponding affiliations are correctly shown.

- Check the questions that may have arisen during copy editing and insert your answers/ corrections.

- Check that the text is complete and that all figures, tables and their legends are included. Also check the accuracy of special characters, equations, and electronic supplementary material if applicable. If necessary refer to the Edited manuscript.

- The publication of inaccurate data such as dosages and units can have serious consequences. Please take particular care that all such details are correct.

- Please do not make changes that involve only matters of style. We have generally introduced forms that follow the journal's style.

Substantial changes in content, e.g., new results, corrected values, title and authorship are not allowed without the approval of the responsible editor. In such a case, please contact the Editorial Office and return his/her consent together with the proof.

- If we do not receive your corrections within $\mathbf{4 8}$ hours, we will send you a reminder.

- Your article will be published Online First approximately one week after receipt of your corrected proofs. This is the official first publication citable with the DOI. Further changes are, therefore, not possible.

- The printed version will follow in a forthcoming issue.

\section{Please note}

After online publication, subscribers (personal/institutional) to this journal will have access to the complete article via the DOI using the URL: http://dx.doi.org/[DOI].

If you would like to know when your article has been published online, take advantage of our free alert service. For registration and further information go to: http://www.springerlink.com.

Due to the electronic nature of the procedure, the manuscript and the original figures will only be returned to you on special request. When you return your corrections, please inform us if you would like to have these documents returned. 


\section{Metadata of the article that will be visualized in OnlineFirst}

\begin{tabular}{|c|c|c|}
\hline ArticleTitle & \multicolumn{2}{|c|}{ Who is the Author of Halakhah? } \\
\hline \multicolumn{3}{|l|}{ Article Sub-Title } \\
\hline Article CopyRight & \multicolumn{2}{|c|}{$\begin{array}{l}\text { Springer Science+Business Media B.V. } \\
\text { (This will be the copyright line in the final PDF) }\end{array}$} \\
\hline Journal Name & \multicolumn{2}{|c|}{ International Journal for the Semiotics of Law - Revue internationale de Sémiotique juridique } \\
\hline \multirow[t]{8}{*}{ Corresponding Author } & Family Name & Volli \\
\hline & Particle & \\
\hline & Given Name & Ugo \\
\hline & Suffix & \\
\hline & Division & \\
\hline & Organization & Università di Torino \\
\hline & Address & Turin, Italy \\
\hline & Email & volli.ugo@gmail.com \\
\hline
\end{tabular}

\section{Received}

Schedule Revised

Accepted

Abstract The Jewish Law (Halakahh) is probably the older legal system working in our time. It is established on a hierarchy of different texts. The oldest and more authoritative is the Torah (the five books of Moshe), then come the Mishnah, the Talmud, the compilation as Maimonide's Mishne Torah and Caro's Shulchan

Arukh, then the responsa of the rabbis. While the authorship of the later texts is more or less clear, the one of the Torah is highly problematic, also in the self-understanding of Jewish hermeneutics. This question is discussed in the present paper not from a philological-historical point of view, but from a semiotic one, trying to understand what devices and regimes of enunciation are enacted by the text in order to establish its semioticjuridical effects. A special double enunciation frame is proposed as the mark of the legislative power in the text, in correlation with another textual device, a sort of divine "signature". The further evolution of the authorship of the Jewish Law is discussed in its relation with the question of the autonomy in the interpretation of the sacred text.

Keywords (separated by '-') $\quad$ Torah - Halakhah - Authorship - Talmud - Enunciation

Footnote Information

Halakhah (literally path, from the root $\mathrm{H}-\mathrm{L}-\mathrm{CH}$ ) is the overall name of the actual Jewish law, that is what actually binds the Jews. We shall see the meaning of this specification later. By "Jewish law" we mean the traditional and religious legal system of Jewish people - not to be confused with that of contemporary Israel, which is secular and presents the key features and authorship of a typical modern democratic legal systems. It should be noted, as I will show later, that the Jewish legal system is probably the world's oldest still widely applied one, at least in certain areas. 


\section{Author Query Form}

\section{亚 Springer}

the language of science

\section{Please ensure you fill out your response to the queries raised below and return this form along with your corrections}

\section{Dear Author}

During the process of typesetting your article, the following queries have arisen. Please check your typeset proof carefully against the queries listed below and mark the necessary changes either directly on the proof/online grid or in the 'Author's response' area provided below

\begin{tabular}{|c|l|l|}
\hline Query & \multicolumn{1}{|c|}{ Details required } & Author's response \\
\hline 1. & $\begin{array}{l}\text { Please confirm the inserted city and } \\
\text { country name is correct and amend if } \\
\text { necessary. }\end{array}$ & \\
\hline 2. & $\begin{array}{l}\text { Please check and confirm the } \\
\text { corresponding author mail id is } \\
\text { correctly identified. }\end{array}$ & \\
\hline 3. & $\begin{array}{l}\text { Please check and confirm the section } \\
\text { heading. }\end{array}$ & \\
\hline 4. & $\begin{array}{l}\text { Please check and confirm Refs. [16, 17] } \\
\text { with intials. }\end{array}$ & \\
\hline 5. & $\begin{array}{l}\text { Please check and update full details for } \\
\text { Ref. [23] }, \text { Ref. [25] with page range } \\
\text { and Ref. [26] with volume no. }\end{array}$ & \\
\hline 6. & $\begin{array}{l}\text { Reference [12] are given in list but not } \\
\text { cited in text. Please cite in text or delete } \\
\text { from list. }\end{array}$ & \\
\hline 7. & $\begin{array}{l}\text { Please provide section headings for 1, 2, } \\
\text { and 3. }\end{array}$ & \\
\hline
\end{tabular}




\title{
3 Who is the Author of Halakhah?
}

\section{$4 \quad$ Ugo Volli}

\author{
Uo Volli
}

\begin{abstract}
Springer SciencetBusiness Media B.V. 2012
\end{abstract}

\begin{abstract}
The Jewish Law (Halakahh) is probably the older legal system working in our time. It is established on a hierarchy of different texts. The oldest and more authoritative is the Torah (the five books of Moshe), then come the Mishnah, the Talmud, the compilation as Maimonide's Mishne Torah and Caro's Shulchan Arukh, then the responsa of the rabbis. While the authorship of the later texts is more or less clear, the one of the Torah is highly problematic, also in the self-understanding of Jewish hermeneutics. This question is discussed in the present paper not from a philological-historical point of view, but from a semiotic one, trying to understand what devices and regimes of enunciation are enacted by the text in order to establish its semiotic-juridical effects. A special double enunciation frame is proposed as the mark of the legislative power in the text, in correlation with another textual device, a sort of divine "signature". The further/evolution of the authorship of the Jewish Law is discussed in its relation with the question of the autonomy in the interpretation of the sacred text.
\end{abstract}

Keywords Torah · Halakhah · Authorship · Talmud · Enunciation

Halakhah (literally path, from the root $\mathrm{H}-\mathrm{L}-\mathrm{CH}$ ) is the overall name of the actual Jewish law, that is what actually binds the Jews. We shall see the meaning of this specification later. By "Jewish law" we mean the traditional and religious legal system of Jewish people-not to be confused with that of contemporary Israel, which is secular and presents the key features and authorship of a typical modern democratic legal systems. It should be noted, as I will show later, that the Jewish legal system is probably the world's oldest still widely applied one, at least in certain areas. 
Although, as we will later see, the Jewish legal system is layered in a complex hierarchy of sources, it undoubtedly considers itself as based ultimately on the text of Holy Scripture (Mikrah or Tanakh). ${ }^{1}$ In fact, according to the Jewish tradition, throughout all the Tanakh only the Torah ${ }^{2}$ (i.e. the Chumash, the Five Books of Moses) is truly normative - and not, for example, the many prophetic passages or 30 the Proverbs, which also show rules, obligations and examples of actions, though they are often used as guidelines for legal interpretation. ${ }^{3}$ Even the second major

1FL01

1 FL02

1 FL03

1FL04

1FL05

1FL06

1FL07

1FL08

1FL09

1FL10

2FL01

2FL02

2FL03

2FL04

2FL05

2FL06

2FL07

2FL08

2FL09

2FL10

2FL11

2FL12

2FL13

2FL14

2FL15

2FL16

2FL17

2FL18

2FL19

2FL20

2FL21

2FL 22

2FL 23

2FL24

2FL25

2FL26

2FL27

3FL01

3FL02

3 FL03

3FL04

3FL05

3FL06

3FL07

3FL08

${ }^{1}$ Corresponding roughly (but with considerable textual differences and organization of the canon) to what in the Western languages, namely in the Christian world is called the Bible. Nevertheless, Mikrah does not mean writing but reading or better proclamation, coming from the root קרא K-R-H, which is the same used in Arabic for the Koran. Tanakh is an acronym structured according to the consonantal Hebrew phonology, which recalls the three parties that compose the Hebrew scriptures: the Torah (Pentateuch), Neviim (Prophets), Ketuvim (Writings or Agiographs). I would like to use this note in order to clarify that the transcription of Hebrew words in this article is not scientific and only aims to facilitate the understanding for the non-expert reader. I want also to clarify that obviously the point of view of this study is not a legal or rabbinic, but only semiotic, and certainly it does not pretends to usurp in any field a decision power that does not belong to the author.

${ }^{2}$ Torah is a semantically rich word, used in different ways in the Jewish tradition. The word Torah (תררה) is etymologically linked to the teaching (מררה), Moreh, is the teacher), to the act of aim and hit (so to be accurate in teaching and doing: the correspondent verb is ירדי ioreh; the sin -het-, consistently has the etymology of a target error), and also to the light (אר, or), with its metaphoric field of lamps, lighting, etc. (which is scattered throughout the biblical text, for example, Prov. 6:23, Psalm 119: 105115, Is 8:20). In practice, we use the word Torah to define all the Jewish study, including "what an expert rabbinical student will say", but mainly for the Torat Moshe, the Pentateuch (in Hebrew also named as Chumash), which is also defined as "Written Torah", while the Talmud and by extension the later interpretive tradition, is often called "Oral Torah". Finally, it often happens that a single law is called the Torah (eg Lev. 6:2, "Torat haolà", the law of the Holocaust, Lv 14:97: "Torat tsar", the law of leprosy; Nm 19:2, "hukkat torah" the statute of the law, etc...) In other contexts, the same rule shall be called the "mitsvah" (commandment), "Hukka" (norm), "Mishpat" (rule). Often these words appear together, as in Gn. 26: 5, Ex 16:28, 18:16 and so on. Those who are usually called in western languages "ten commandments", in their Hebrew name lose this imperative tract: they are called "asseret hadibrot" meaning "ten words" (hence properly "Decalogue"). The differences in all this complex terminological field are not clear. Beginning from the Talmudic discussion (Makkoth 23b), the main obligations that the Jewish laws imposed on individuals or communities (not so for example the legal obligations of contractual aspects etc...) are summarized in "613 mitsvot" or precepts. The number 613 is explained as the sum of 248 Mitsvot "laasse" or positive and 365 "lo taassé" or negative laws. About these numbers, there is plenty of Kabalistic thought. Suffice it to say here that 365 is defined as the number of days of the year, 248 that of the "bones" of the human body (in the Talmudic conception) and the number 613 is usually related to the "numerical value" or "ghimatria" of the word Torah which is actually 611 . But the sum becomes right with the addition of 2 for the first two words of the Decalogue, that "God signature" about which we will discuss later. For a summary list of the 613 mitsvot, cf. http://it.wikipedia. org/wiki/613_mitsvot. The most authoritative discussion is the Sefer Hamitsvot ("Book of Precepts") of Maimonides, which can be found on the Internet in its original language (http://www.daat.ac.il/ daat/mahshevt/hamitsvot/shaar-2.htm).

3 The rule is based on the well known passage of Deuteronomy (30:12) which states that "The Torah is not in heaven," reinterpreted by TB Bava Mets. 59b to show that the practical rule of Judaism, the Halakhah, is established in the discussions of the sages, following their majority (Es.23:2). Then there is a passage in TB Baba Mets. 2b that says that one does not follow the interpretation given by the prophets about the Chumash. Maimonides in Chapter 9 of his "Foundations of the Torah" (the beginning of the Mishna Torah), specifies that a prophet has no right to innovate halakhot, and that its purpose is just to remember to look at the Torat Moshe (i.e. the Pentateuch), and cites the passage of Malakhi (3:22) that is read as Haftarah of Shabbat Hagadol and is also the conclusion of the Tanakh. In fact, some laws are 


\begin{tabular}{|l|lll|}
\hline & Journal : 11196 & Dispatch : $\mathbf{1 2 - 4 - 2 0 1 2}$ & Pages : 20 \\
& Article No. : 9268 & $\square$ LE & $\square$ TYPESET \\
MS Code : SELA-D-12-00020 & $\square$ CP & $\square$ DISK \\
\hline
\end{tabular}

The Author of Halakhah?

source of Jewish law, the most detailed one, which directly leads the current religious law, i.e. the Talmud, presents itself predominantly as a clarification (in the form of discussion) of the contents of the Torah. ${ }^{4}$ So the problem of the authorship of Jewish law brings us ultimately to inquire about the one (or the One) who is the author of the Torah.

The question would allow, of course, two possible lines of response. On the one hand we can historically and philologically examine the process of composition of the biblical text. This task has been undertaken by the biblical philology ever since the Spinoza's pioneering work in the Seventeenth century, reaching the apogee of its credibility with Wellhausen's work in the middle of the Nineteenth century and complicating and shattered into conflicting versions throughout the twentieth century. ${ }^{5}$ The basis of this paradigm is the idea that the biblical text should be broken down into a number of original parallel or synoptic "documents", in analogy to the Gospels model (hence the name of "documentary hypothesis" used to define this stream of studies), which supposedly were melted by editors in the received text. The documents hypothesized by Wellhausen were four: "E" (so characterized because in it the divine name Elohim is predominant); " $\mathrm{J}$ ", (where the divine name is the Tetragrammaton, which in English transcription begins with this letter); "P", or Priestly (because in it the interests and concern of a group of priests would be reflected), and " $D$ " or Deuteronomy, (because the content of the vast majority of the last book of the Pentateuch, i.e. Deuteronomy, would be attributed to it).

Over time, the evolution of this theory broke down even these documents into several sub-documents and it was assumed that they had also been recast by a number of partial editors. The history of the Documentary Hypothesis after Wellhausen shows a great variability of the paradigm, which fails to stabilize the analysis of text documents, nor their respective dating and authorship attribution. Considered from outside, the Documentary Hypothesis appears today as a predominantly Protestant point of view on the Bible, with strong ideological traits, that appears of little relevance for our purposes. The critical remark may seem hard but it is justified not only because this stream of biblical philology denies, in its majority, the received structure of the text and in particular the primacy of the Pentateuch, always recognized by the Jewish tradition, which is the frame for our authorship question, ${ }^{6}$ but also because, ideologically, it frames almost everything in

\section{Footnote 3 continued}

made on Neviim, but clearly the sages feared that it could be too easy to pretend to be prophets and change the halakhah. There is a passage in Megillah 2b (parallel Shabbat 104a), where the verse "And these are the words" (Lev 27.4) is used to emphasize that the prophets can not innovate, but they can only reintroduce former things that had been forgotten: "from now on in a prophet is not allowed to innovate." The same goes in Yoma 80a as regards the minimum of the sanctions. In...Temurah 16a the same principle is reaffirmed, talking about the fact that many halakhot were lost after Moses, and the theological root is elle hadevarim: i.e., only these are the words of God, not that will be added. (thanks to Haim Cipriani, for this personal communication). See also Maimonides, Introduction to the Mishnah, I, 2.

${ }^{4}$ For some explanation about the Talmud, see later. Introductions and explanations for general reference are, Steinsalz [19], Stemberger [20].

5 Cf. Nicholson [13].

${ }^{6}$ For a review of all these positions, written by a scholar who defends "the Legacy of Wellhausen", see Nicholson [13]. As our object is the authorship of Jewish Law, which is defined by the Jewish tradition as 


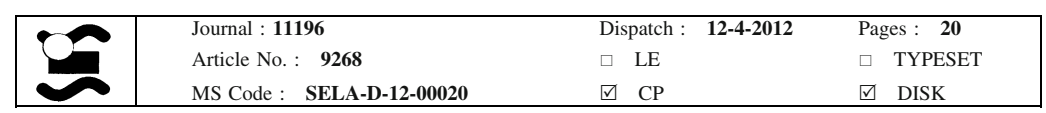

a Christian framework, for example placing the emphasis on the prophetic writings and underestimating those of the Pentateuch ${ }^{7}$ and in particular its legal portion.

Moreover, the influence of Protestant theology is evident in the way of considering the complex textual structure: for example in the analysis of the Bible as "salvation history"; in the attempt to identify here and there some explicit faith declaration or, in their language, "creed"; in the prevalence given to the prophetic "ethic" preaching and in disregard for what Judaism considers the main aspect of the scripture, the legal content. These lines of analysis have not been accepted by the Jewish religious culture, who has proposed alternative hypothesis. ${ }^{8}$

Of course, religious affiliations or ideologies aren't good reasons for accepting or refusing a scientific hypothesis. But the clear fact of a large plurality of interpretations of the Documentary Hypothesis, which are not able to converge, suggests that the research paradigm is somehow wrong or too ambitious. It would be interesting, although not conclusive about its further use, knowing who and when actually composed the Torah or its "documents"; but despite two centuries of wide efforts in this direction no shared answer has been found. It is possible to suggest a different approach: the semiotic one. In general, semiotics is not interested in knowledge of as to who are the empirical authors of a text, what were their intentions and social interactions, even when that is known; it looks to the texts from the reader's point of view, considering what is the representation of the author and his/her ideology included in the text is, what kind of Encyclopedia it entails etc.

For these reasons, the question of who was the empirical author (or authors) of the Torah on the historical-philological field, will not be considered any further in this article. I will instead address the authorship inscribed in the text, that is, the author (or, as we will see, the hierarchy of authors) who is implicitly communicated and assumed by the text through complex enunciation mechanisms. It is important to understand that our question does not concern the authority supporting the binding character of the text, which is, of course, exposed by the text as God himself, as Creator and hence as Master of the world, all-powerful and mindful of the Jewish people. The problem in this paper is authoriality, i.e. the semiotic instance assumed by the text itself as signing, constituting and validating the legal text of the Jewish Law. I will discuss this after the self-interpretation of the Jewish tradition, i.e. the way it is treated inside the text and in the following hermeneutic work on it. We have rich continual traces of this hermeneutic elaboration since the biblical texts coming after the Torah, through the Mishnah and the Talmud, till the big Middle Ages commentary and the following discussions. Although it separates the different layers of this elaboration, this article aims to examine the whole selfunderstanding of the Jewish legal tradition, i.e. the consensus through the ages about some basic principles, as "Torah", in the wider sense (cfr. Volli [26]).

\section{Footnote 6 continued}

originated in the Pentateuch, a theory devaluating and destructuring it can hardly be our point of departure.

7 Often it is recast together with the book of Joshua, in an "Exateuch", which is a "discovery" of the Documentary Hypothesis writers, without any known support in the history of the text reception before it.

${ }^{8}$ For a brief but effective argument for these positions, see Cassuto [6]. 


\begin{tabular}{|l|lll|}
\hline & Journal : 11196 & Dispatch : $\mathbf{1 2 - 4 - 2 0 1 2}$ & Pages : 20 \\
& Article No. : 9268 & $\square$ LE & $\square$ TYPESET \\
MS Code : SELA-D-12-00020 & $\square$ CP & $\square$ DISK \\
\hline
\end{tabular}

The Author of Halakhah?

The Pentateuch is attributed by the Jewish tradition and, above all, in the text itself to Moses: (Ex 17:14, 24:3, 4, 7; 32:7-10, 30-34; 34:27, Lev. 26: 46; 27:34, Deut. 31:9, 24, 25); as we find in Nm: 9:22 with an expression important for the Jewish liturgy, the Law is "written by Moses in the name of God". It is considered unchangeable and closed, in the sense that nothing can be taken away from the text and nothing can be added (Dt 12:32, $4: 1-6$ ). Also, it is regarded by the tradition as wholly given at the revelation at Sinai (Torat Moshè min Sinai), even if tells events after that time and even after the death itself of its author. This paradox, of course, is not neglected by the traditional comment which handle it in terms of prophecy: not in the sense of free forecast of the future, as in the popular meaning of the word "prophet", but in that of divine dictation, which is the true meaning of this word (cf. Volli [26]) and hence of the divine omniscience that justifies it. We are interested in this detail mainly because it provides another clue to the problem of authorship in this text, because Moses is "the greatest of prophets" (Maimonides). The authoriality of a prophet is a very special and limited one. We must consider it in some detail.

The prophetic discourse, at least in the Tanakh, has a special nature: it is not a personal word, it belongs literally to God. The prophet is not the real subject of his speech, rather he is a tool, manipulated, even unwillingly as in the case of Jonah, a tool chosen to speak to the man, a kind of megaphone: hence he may be called "the mouth of God.", "You don't have to seek advice from my mouth" i.e. from the prophet, God rebukes his people, using that same voice (Isaiah 30:2). In Jeremiah, God promises: "If you come back, I will come back, you'll be the at my presence [...] you will be my mouth" (Jer. 15:19). Very often the talk of the prophets contain similar formulas: "Y-H-V-H $\mathrm{H}^{9}$ speaks "says Isaiah $(1: 2 \mathrm{ff})$," The word came to Jeremiah from $\mathrm{Y}-\mathrm{H}-\mathrm{V}-\mathrm{H}$ " (Gr 7:1) "Listen to what is the word that proceeds from the Y-H-V-H" (Ezekiel 33:30; Is 1:10); "So says Y-H-V-H" (Isaiah 8:1) "oracle of Y-H-V-H" (Is 15:1, 17:1 and passim). The prophet is therefore "the man of God" (1 Kings 4:7), or "of the spirit" (OS 9:7). The Bible does not distinguish between their words and the word of God: "The house of Israel will not listen because you do not want to hear me" (Ezekiel 3:7). "For I sent my servants the prophets, day after day, but they did not listen Me "(Jer 7:25)." Rejecting their word means then rejecting God"' (Zechariah 7: 9-13, cf. Deuteronomy 18:18ff).

The prophet is an instrument of God because God is manifested "through (beyad) his prophets". The expression beyad, which has also the instrumental meaning of "through", "by means of", literally means "in the hand". Thus we find, again with the use of beyad, "the mitsvah of Y-H-V-H given through Moses" (Num 36:13), "the mitsvah of $\mathrm{Y}-\mathrm{H}-\mathrm{V}-\mathrm{H}$ indicated by the prophet Haggai" (Ag. 1:2, 2); "the words that $\mathrm{Y}-\mathrm{H}-\mathrm{V}-\mathrm{H}$ proclaimed by the ancient prophets" (Zech. 7:7-12). The prophet is thus "mouth", but also "hand". And Moses being "the greatest of the

\footnotetext{
${ }^{9}$ I will transcribe here and later the Tetragrammaton jod-he-vaV-He (so to speak that is the proper name of the Lord, not to be uttered following the Jewish law) with the Western corresponding letters. In nonliturgical context the Jewish tradition replaces it the definite description Hashem, which I will sometimes literally translate "the Name". The way of naming God in the Jewish contest, depends on semioticliturgical rules that raise fundamental semiotic questions. For a discussion of the divine names in the Jewish tradition cf. Volli [24]. Normally in Western languages the current translation for this term is "Lord". I will not use it, as it has deep theological implications, that I prefer avoid in this discussion.
} 


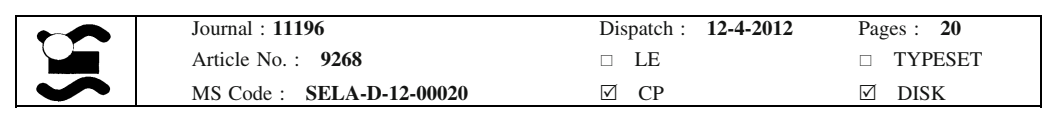

prophets" ${ }^{\prime 10}$ and the Torah the text of his prophecy, still in all of the world's Jewish synagogues, reading the Torah is introduced by a public presentation of the text illustrated by a phrase that sums up the way the tradition understands the authorship of the Jewish law: "vezot haTorà asher sam Moshè livnè Yisraèl, al pi Hashem, beyad Moshe", i.e. "and this is the Torah that Moses presented to the children of Israel, from the mouth of $\mathrm{Y}-\mathrm{H}-\mathrm{V}-\mathrm{H}$ by the hands of Moses."

The expression "the mouth of $\mathrm{Y}-\mathrm{H}-\mathrm{V}-\mathrm{H}$, by the hands of Moses" can be interpreted as alluding to the figure of dictation, certainly traditional but not expressly stated by the text. Only about the second writing of the Decalogue, does the Torah specify that it was dictated; indeed the first version was graved in two stone tables directly from God (Exodus 24:12; 31:18, 32:15-16; Deut. 5:22). After their breaking by Moses because of the golden calf mishap, the tables had to be written again. First Moses obteined the promise of a second writing by God (Ex: 34:1), then he was ordered by God to do it himself: "Write down these words, because on the basis of these words I have made a covenant with thee and with Israel" (Exodus 34:27 ff). This episode is an important example out of the very small number of cases in which the prophets are commanded to write some lines (Ex 17:14, 24:4, 34:1, Dt 5:22, 31:9, Isaiah 30:8, Has 2,:2, Gr 36:2-4, Ezekiel 24:2), cases in which the word "book" is also often used. ${ }^{11}$ It should be noted, finally, that prophets do not always endorse what they must say (the canonical case of such an opposition is Jonah, who does not want to warn and save the inhabitants of Nineveh, as it is ordered by God). More, prophets do not always even fully understand the consequences of their prophecy. It is the case of a famous Midrash ${ }^{12}$ of the Babylonian Talmud, Menachot 29b.

Rabbi Yehuda said in the name of Rav: When Moses went up on high, he found the Holy One sitting and tying crowns on the Holy letters. He said to the Holy One:.Ruler of the Universe, who is holding back Your hand?. The Holy One answered:.There is a man who will appear at the end of several generations and Akiva the son of Joseph is his name and he will need these crowns, because from each and every thorn he will derive scores and scores of laws.. He said to Him,.Ruler of the Universe, show this man to me.. The Holy One said, Turn around! So, Moses went and sat in the back of Rabbi Akiva's class, and he had no idea what they were saying. He became weak and disoriented. Soon the class reached an issue and a student asked,.Rebbe, what's your source for this ruling?. He said,.It's a law of Moses from Sinai.. Moses was relieved. Moses returned to the Holy One and challenged Him,.

${ }^{10}$ This is the seventh of the thirteen principles of faith proposed by Maimonides (Pirush Hamishnayot, treated Sanhedrin, Chapt. 10) and reflects a tradition that starts from the very conclusion of the text of the Torah (Deuteronomy 34:10), "lo kam be Yisrael ke Moshe od navi", "did not rise in Israel a prophet like Moses".

${ }^{11}$ On the very complex way the expression sefer (usually translated as "book") is understood in the Tanakh, cf. Volli [25].

${ }^{12}$ Noun from the root D-R-SH, which means petting, soliciting, and hence commenting. It is a rabbinic commentary that may be legal, theoretical or narrative; most often it is understood as a legendary and homiletic expansion of the Torah developed in the rabbinic tradition. For a detailed discussion, see Banon [5]. 


\begin{tabular}{|l|lll|}
\hline & Journal : 11196 & Dispatch : $\mathbf{1 2 - 4 - 2 0 1 2}$ & Pages : $\mathbf{2 0}$ \\
& Article No. : 9268 & $\square$ LE & $\square$ TYPESET \\
MS Code : SELA-D-12-00020 & $\square \quad \mathrm{CP}$ & $\square$ DISK \\
\hline
\end{tabular}

The Author of Halakhah?

You have a man like this and yet. You are giving the Torah through me?. The Holy One answered,.shut up! That's the way these thoughts ascend to me! Moses asked,.Now that you've shown me his Torah, show me his reward.. The Holy One said,.Turn around!. He turned around and saw people weighing Rabbi Akiva's flesh in the marketplace. Moses hollered,.This is his Torah, and that was his reward?. The Holy One answered, shut up! That's the way these thoughts ascend to me! ${ }^{13}$

One should not make the mistake of taking this anecdote as meaningless and naive. The conventional narrative of the Midrash is a systematic way of conveying complex problems through a "concrete" rhetoric (Banon [5]). This story is important in relation to our discussion, because it does not only doubts somehow the biblical authorship (Moses is represented as the regular author, but it is God who writes the text decorations from which in the future halakhot i.e. laws will be taken) but also emphasizes the importance of creative interpretation, on which we will return later. The relation between the God who dictated (or just inspired) and now is copying and decorating the scroll, and the man to whom the book is attributed, is very complex - as it is complex the relation between rabbinical evolution (chiddush) and fidelity to the source. In our modernity we see a radical opposition between invention and conservation - in the Jewish Tradition (and actually in all ancient word: the Latin meaning of "inventio" is about finding something not creating it anew) things are different. $^{14}$

So, it is not clear in the text (except on the basis of an hermeneutical act of faith) whether all the Torah was dictated by God to Moses, or inspired, or otherwise constructed. Likewise one cannot easily find in the Torah a textual or narrative justification of the belief deep rooted in Jewish mysticism that the Torah precedes the creation itself, being a kind of model of the world. It will be then convenient, in order to better understand the authorship of the Torah-the authorship which is relevant to us, the implicit and self-described one-to try a closer look at its text. Here in fact the problem of the authorship is reduced to the enunciation of authorship: whom does the Torah say is saying its text? (or writing it?).

The outer narrative frame of the Torah, in the terms of Genette [7] is strictly heterodiegetic, at least in formal terms. If we did not know already that the One who dictates/authors is the divinity, we would not be able to know it in terms of explicit narrative. All the story is seen in the third person and from afar: the Creation, the Flood, Babel, the stories of the patriarchs, the exodus of the people of Israel from Egypt, their experiences in the desert, the same divine revelation... Beyond any philological theory about the various "documents" composing the text, one can reconstruct a perfect continuity from the narratological and enunciation point of view, at least for the outer frame of the text (i.e., without taking in consideration for

\footnotetext{
${ }^{13}$ http://www.hillel.org/NR/rdonlyres/F0514602-925C-4343-A0A4-392CED4949CC/0/Understanding Shavuot.pdf. Cf. Rabello [15]:51.

${ }^{14}$ See the opposition between two kind of innovations, shinui and hiddush, as defined in Askenazi [1]:248-253.
} 
the moment those textual layers of "enunciated enunciation" 15 that Genette [7] calls metadiegetic). Even Deuteronomy, although it has an strongly metadiegetic and homodiegetic internal form, consisting of three speeches held by Moses in first person, is opened and closed by an heterodiegetic frame: an introduction for presenting space and time ("These are the words that Moses spoke to all Israel" etc. (Deuteronomy 1: 1-5) and the end in Chapter 34 with the description of his author death from the outside ("Then Moses went up from the plains of Moav on Mount Nevo," etc.).

The narrator implied in the frame of the Torah and in many of its narrations, never explicitly defined in its identity, is "omniscient" in narratological (and therefore weak or metaphorical) terms, or rather his omniscience is strong enough to bear witness to events that could not be attended by any mortal such as the creation of the world, or to narrate people's (and even God's) internal subjective states as beliefs and feelings. But in the text, we note only the evidence of this narrative or weak omniscience, alike to that which can be found in much part of Western literature, starting from Homer and Hesiod who claim to know secrets and thoughts of the gods and men. That the weak omniscience of the narrator should be identified with the true and strong one reserved to the divinity, is a conclusion that can be drawn only if one accepts as matter of faith that the biblical narrative is also literally true.

By contrast, from the beginning of the text (from the third word: "Bershit Barà Elohim"), God is an object of narrative, a "character" or an "actor" that is spoken in the third person — and that by the way is very often said to speak. ${ }^{16}$ Thus, reading the Torah, we are confronted to a "narrative character" with the quality of being an Author or Creator or Inspirer or Dictator of the text (without prejudice now and for the rest of this essay about the question of which of these definitions is correct), allpowerful, good, caring, compassionate etc. We meet also as a narrative character a material author, recognized as such by tradition and by some clues of the text, a "hand" that contributes somehow to the text (in an equally not-decided-for-us-here way), and confront the Pharaoh, leads the Jewish people etc. Thus both the authors are also characters of the text, ${ }^{17}$ who speak among themselves and with others, give orders and proclaim laws. This is particularly meaningful in this inquiry, because among the objectives of the text - perhaps even its main purpose, or even the unique

15FL01

$15 \mathrm{FL} 02$ $15 \mathrm{FL} 03$

15FL04

16FL01

16FL02

$16 \mathrm{FL} 03$

16FL04

16FL05

17FL01

17FL02

17FL03 17FL04
15 I remember that for "enunciated enunciation" semiotics intend that within an utterance (e.g. a narration) there is the statement of a character - no matter if a "true" historical or a fictional one. So it is a kind of act of enunciation, not in the real world but in that of the story, hence not a live word but its narrative.

16 By this statement of course I don't mean that God is only a literary character, as some people think today. I will just say that when we study the text of the Torah with the techniques of contemporary narratology, we find characters (actors) actants, speech, focus, storytellers, just as if one looks at it with the techniques of grammatical analysis there are subjects, predicates, parataxis and hypotaxis etc. without of course implying that the Torah as such, its story and those who act in it are reduced to these categories.

17 For example, the passages in which Moses is ordered to write "this Torah" that may be the specific law which is spoken or the entire text. In any case, as in this discussion we accept the text as it is, since we are interested in its consequences and not enter into the philological problem of its composition, so we work using the traditional attribution, without discussing it. 


\begin{tabular}{|l|lll|}
\hline & Journal : 11196 & Dispatch : $\mathbf{1 2 - 4 - 2 0 1 2}$ & Pages : 20 \\
& Article No. : 9268 & $\square$ LE & $\square$ TYPESET \\
MS Code : SELA-D-12-00020 & $\square$ CP & $\square$ DISK \\
\hline
\end{tabular}

The Author of Halakhah?

one, as we will soon see-there is their legislative activity, which is also a narrative object.

In the text of the Torah the laws are all explicitly presented as divine provisions, i.e., as speech acts of the divine character. They never appear in the narrative frame or in any impersonal form, but are always attributed to a divine "enunciated enunciation", often in a peculiar and quite complex form, as we will see. Very often the verses intended to be taken as laws (and that actually became the ground of Jewish law) are also "signed" in the text, that is they are characterized by a closing clause as "Ani $\mathrm{Y}-\mathrm{H}-\mathrm{V}-\mathrm{H}$ "18 meaning "I, $\mathrm{Y}-\mathrm{H}-\mathrm{V}-\mathrm{H}$ " or "I am $\mathrm{Y}-\mathrm{H}-\mathrm{V}-\mathrm{H}$ " (often with additional specifications, such as "Y-H-V-H, your God," or, "Y-H-V-H that drew you from the land of Egypt" and the like). This signature, which appears also alone as the first "word" of the Decalogue, is not mandatory to establish the legally binding status of the rule, but appears very often and many authors maintain that it provides special solemnity to the injunctions to which it is affixed.

Beyond the question of signature, the fundamental fact remains that the authorship of the law is always attributed expressly to God, to which the foundation of the legislature is reserved. Thus, in those cases there is always an "enunciated enunciation" attributed to the Divinity. The law, in this context, is essentially a kind of divine order and in fact "mitsvah", the word that most correctly designates halakhic rules, derives from the Hebrew TS-V-H root, which means to yoke, to impose. Not all the divine commands, however, assume a truly legal character, there are specific orders directed at individuals or individual groups at certain times (such as the request made to Noah to build the Ark) or generic ones for all mankind ("be fruitful and multiply") These commands do not belong de jure to the specific Jewish law as their target is improper, but can be allowed to enter it by analogy or by extension or as an example. Actually, the true biblical laws are typically characterized by a form that qualifies the command as law. The main point is that they are directed explicitly to the "bené Yisraell", the children of Israel, that is the Jewish people.

In order to understand what belongs to Jewish law it is therefore necessary to consider not only the author but also the declared recipient of the message. It is in the correct coexistence of the two terms in the text that the validity of the norm is ground, but this coexistence obviously cannot be but in the text. In fact only those orders are accepted as Jewish law, that God addresses in the Torah specifically and explicitly to the community of the Jewish people (even when, from a practical point of view, the norm involves only a fraction of it, such as the rules on the sacrifices, which can be performed only by priests). It is interesting to note that what allows one to recognize this relationship in most, if not in all, cases is an enunciation mark: in order to be recognized as law, it is not enough that the rule be simply expressed or commanded by the divinity, but the text must express it through Moses being ordered to communicate it to the Jewish people. In these cases communications pass through three logical levels:

18 The ambiguity is due to the fact that in Hebrew language the copula in the present tense is not usually expressed by a separate word and any combination of a subject and a verbal predicate, or as in this case a pronoun and a noun can be always understood as predication. 


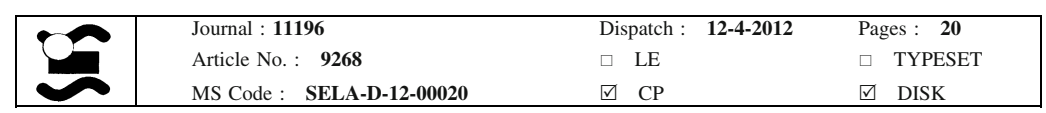

1. Frame level ${ }^{19}$ in which the narrator in third person, whoever he is, says that God (usually named in these cases as $Y-H-V-H$ ) speaks to Moses (often in Hebrew: Vaiomer $\mathrm{Y}-\mathrm{H}-\mathrm{V}-\mathrm{H}$ el Moshe). In this frame level, usually very few details of space and time are given (for example, He spoke "at Mount Sinai" or "after" a certain fact). Often the frame sentence ends with the expression lemor, literally "to say", that serves as the opening quotation mark of a statement or, more technically of an enunciated enunciation.

2. The second level (subject to a further debrayage and expressed as imperative speech act, in the singular number) is what is commanded to Moses, a very simple order that has just the form of "speak to the children of Israel" (emor el bené Yisrael), or "to the community of Israel", or "to all Israel" (details that are often significant in terms of interpretation, but don't matter here for us) "and tell them", a clause that opens a second nested enunciated enunciation.

3. Third level The object of this second speech act (after a third debrayage) is again in the imperative mood but plural in number: it is that of the law or set of laws that are often punctuated by the signature that we have already dealt with. Compared to the previous level, this time the represented speaker is the same (God), but while before it was a simple command to be uttered to Moses to say, here we read the description of another provision to be disseminated to all the Jewish people.

Thus the rule is given not as direct order but rather as a description of an order or as its matrix or model: a special status that is expressed in the fact that usually such sentences are formulated in the third person (and by the way in the future tense i.e. imperfective aspect, that in the language of Torah often cannot be distinguished from the imperative). Since the imperative is typically linked to the axis I-thou of communication, an imperative sentence in the third person is always problematic. In this case, this mode is used to make the command temporally unlimited, to exempt it from the space-time conditioning of the utterance situation.

After a few verses or a few chapters, the act of legislation closes, and we are taken back to the frame level, sometimes with an explicit formula, such as "this is what $\mathrm{Y}-\mathrm{H}-\mathrm{V}-\mathrm{H}$ said to Moses" in the given circumstance. The same organization, with few trivial differences of grammatical form, can be found in the homodiegetic talks attributed to Moses which represent the biggest part of Deuteronomy. ${ }^{20}$

${ }^{19}$ A level that is subject, in semiotic terms, to the first basic debrayage that every text undergoes, detaching it from the I-here-now of the actual utterance or writing of the text. "Débrayage" literally means disengagement. It is the disjunction or the separation of the text from the actual situation of enunciation or writing and then the creation inside the text of simulacra (tracks, marks, indicators) of another I-here-now. Thus it entails the projection of one or more subjects (= actors) other than those of the enunciation, and of a space and a time different than those of the enunciation.

${ }^{20}$ Further evidence of the need for a double enunciational frame can be found in those numerous episodes where Moses (or both Moses and Aaron, in some cases) receive the command to do something, without it becomes law. It's the case, of course, of the instructions for the dialogues with the Pharaoh in the first chapters of Exodus, but also of the institution of the census at the beginning of Leviticus (chapt. 1-4): " $Y-H-V-H$ spoke to Moses [...] saying so [lemor]: Count the people of the whole community of the children of Israel," etc. (Lev. 1:1-2). This is a complex operation that requires a broad cooperation (wit the appointment of supervisors of each tribe, etc....) But the order is not intended to ground a law for establishing censuses, which indeed is considered forbidden in Jewish tradition, but only to hold that 


\begin{tabular}{|l|lll|}
\hline & Journal : 11196 & Dispatch : $\mathbf{1 2 - 4 - 2 0 1 2}$ & Pages : 20 \\
& Article No. : 9268 & $\square$ LE & $\square$ TYPESET \\
MS Code : SELA-D-12-00020 & $\square$ CP & $\square$ DISK \\
\hline
\end{tabular}

The Author of Halakhah?

This account of the need for a double enunciation frame may help to clarify the first famous question which opens the Rashì influential commentary on the Torah, ${ }^{21}$ commenting its very first verse. Rashì begins quoting from his master (and probably his father) Rabbi Yitzhak, the problem of why the Torah starts from as early the creation of the world, instead of beginning, as it would seem logical to a legal mind, from the enunciation of the first mitsvah, located by him in the Exodus verse that prescribes that the month of Nissan, in which the Jewish people came out from Egypt, "will be for you the first of the months" (Ex. 12:2) We are not interested here in the response of the commentator, though it is highly significant, but in his own question. First of all, we note that the question implicitly justifies the assessment of the Torah as an essentially legislative text, and mainly the identification of the Teaching with the Law, as we pointed out early. Second, it makes it clear, tough here too in an implicit way, that only certain provisions have a directly legislative character, as we have seen. Typically it is argued that they are those particularly affecting the Jewish people.

For instance, neither the prohibition of murder implied by the episode of Cain, nor that of adultery, which can be detected in the episode of Sarah and the Pharaoh, would be considered Jewish laws, because these rules are not formulated in the imperative form, but only through a narrative implication, and because they do not concerns only the children of Israel (however this last point is debatable, because the prohibition of adultery and murder actually become mitsvot, Jewish rules, later in the text but precisely through an explicit order proclaimed even in the most important list of Jewish rules, the Decalogue). ${ }^{22}$

But there is at least one other notable exception, the law of circumcision, which is given to Abraham explicitly, with a clear legislative language, the future without limits, and the third person plural (Gen.17:10-15). It is true that this rule applies to all descendants of Abraham and thus to the Arabs (descendants of Ishmael in biblical terms), the Midianites, the Edomites, etc., and even to the Amalekites; and it is true that the custom of circumcision is in fact shared until now by the Jews with the Arab world, but there is in the Torah no prevision of blame or punishment for these people if they do not honor such obligation. Moreover, the religious meaning of circumcision for the Jewish people is very different than for its neighbors: only in Israel the circumcision is a mandatory requirement, the first that singles out the Jews. Probably, the law of circumcision can be considered as established at this point, as it is shown by the following biblical stories (for instance, that of Shimon and Levi's revenge for the violence suffered by Dinah, two generations later:

\section{Footnote 20 continued}

single enumeration. Therefore it lacks the double frame. If it had been written in such terms as " $Y-H-V-$ $H$ said to Moses: Say to the children of Israel to count" etc., it would then probably become a law.

21 Written in France in the mid-eleventh century. Cf Rashi [16], ad loc.

22 All universal norms, which are known in Talmudic language as Noachic ones for allegedly be ordered to Noah, even though the Torah does not mention them directly but only perhaps hints at them, are also Mitsvot. The codification, which contains some pretty bold interpretations of apparently not legal passages from the Torah, is established in a midrashic source: Genesis Rabbah 16:6. Cfr. Rabello [15]: 7. 


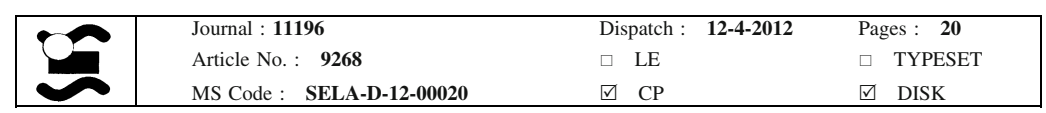

362 Gen 34:14-17). ${ }^{23}$ But Rashì, having to mention in his commentary the first law of 363 the collective people of Israel, does not refer to it, but to the command of the first 364 month, which prima facie seems much less relevant. In fact, the order of 365 circumcision does not have the structure of double frame that we have underlined, 366 but appears in the form of a simple enunciated enunciation (of God), while the order 367 to consider Nissan as the first month responds to the structure that we have 368 described. $^{24}$

Everything we have said so far allows us to reach a provisional conclusion. With regard to the Torah, the authorship of the Law (an authorship that does not necessarily identify the empirical author of the text, as we have seen) is exactly this double divine enunciated enunciation to be mediated by the prophet. Maybe this is meant exactly by the enigmatic expression on which we have wondered so far: al pi Hashem, beyad Moshe.

It should be noted that the normative content of the Torah is not just that of divine origin. Divine orders are to be executed to the letter, which the text shows repeatedly hosting a double explanation of the same details, the first in the form of orders, the second in that of their execution. ${ }^{25}$ But Moses also happens to prescribe rules of which we trace can be found in the divine speech, for example when prescribing a period of chastity before revelation (Ex. 19:15), or when he decides the appointment of judges on the advice of his stepfather Ytrò (18:17-26). ${ }^{26}$ It is not possible to say whether these rules are underlain by divine order or more or less tacit

23 "One cannot be entirely sure of the existence of a circumcision law at this stage; it is safer to talk about a costume, which from the way itself in which Levi and Shimeon and communicate it in Shechem, seems to be part of a tribal culture more that being a religious principle: they do not say ' $\mathrm{G}-\mathrm{d}$ ordered us that ...' but only that 'it is a shame' to give our sister to an uncircumcised man and talk of becoming one people, but no more." Rabbi Haim Cipriani, personal communication.

24 Actually things are not exactly this way; i.e. in this case the clause of the second frame immediately follows the proclamation of the rule, which is directed only to Moses and Aaron: "Y-H-V-H spoke to Moses and Aaron in the land of Egypt in these terms [lemor]". "This month is for you the head of months that will be for you the first of the year. Speak to the whole community of Israel, telling them on the tenth day of this month" etc. (Ex. 12: 1-3). We must assume that the legislative status also extends to the Nissan definition, although when the text records Moses exact obedience to the order and his speech to the "elders of Israel" (Exodus 12: 21) the privilege of the month is not mentioned.

25 The most typical case is the construction, in the wilderness, of the Tabernacle, its furnishings and priestly vestments, every small detail of which is very carefully prescribed in several chapters of the book of Exodus (25-31) and then executed with an equally detailed and long description (capp. 35-40). Between the two descriptions, one in the second person of the future tense and the other in the third person of the past tense, however, there are small but significant differences (for example, in the order of operations), which were often commented upon. About the enforceability of the legislation, it is interesting noting the frequent use of the verb "to do": the regulations are often qualified "to do" (cf Volli [23]). A famous example of the proper attitude in receiving them is the promise "we will do and listen" (first "do" and then "listen"), as the Jewish people responds to the Revelation (Ex. 24:7), which became the subject of a famous commentary by Levinas $[9,10]$.

26 Appointing judges is also, according to the sages of the Talmud, one of the seven "Noah's laws" mandatory for all people (all the sons of Noah). 


\begin{tabular}{|l|lll|}
\hline & Journal : 11196 & Dispatch : $\mathbf{1 2 - 4 - 2 0 1 2}$ & Pages : 20 \\
& Article No. : 9268 & $\square$ LE & $\square$ TYPESET \\
MS Code : SELA-D-12-00020 & $\square$ CP & $\square$ DISK \\
\hline
\end{tabular}

The Author of Halakhah?

384 divine agreement, ${ }^{27}$ or whether this is the beginning of Jewish people's autonomous 385 power of human legislation, a power that will develop later. The fact remains that 386 these rules, established without the formalities that we have said, have not been 387 considered later in the formal group of mitsvot, unless there are other sources for 388 them.

This consideration raises the central problem of the later interpretation of Jewish law. The Torah is not a code, it lacks the systematic order and the hierarchical structure that are needed for being a code. It is instead a narrative containing mostly normative contents. They are often proposed in the enunciational manner that we have seen, but sometimes they are not. They are often repeated several times, as for the rule of respecting Shabbat. At other times seem at odds with each other, as those prescribing how to cook the Passover sacrifice. ${ }^{28}$ There are also many laws, universally recognized as such in the Jewish world, that are not grounded in an explicit statement of the Torah, but later derived from it by way of reasoning. There are rather generic laws, such as the very emphasized ones that require respect to the Shabbat, but without specifying exactly what this respect consists in. The exact rules were made explicit later.

No wonder, therefore, in finding that the written Torah (the Chumash, as I explained above, the five books of Moses) is indeed the main source of Jewish law and can not be changed-but it is incomplete. Hence it is necessary to assume, although we have no direct evidence of it, that a process of completion, sorting, reconciling the tension between different points, further explanation of the meaning and exceptions was implemented beginning immediately after the writing of the Torah. No doubt, this work was done by jurisprudence, i.e. it was the result of decisions by authorities; but from a certain point onwards it was also carried on at a theoretical level. This process of reflection and completion is called the "oral Torah", because until the Romans caused Jewish state's final loss of autonomy in the first century, it was deemed unacceptable to write down the results of such process (because this would have been tantamount to emulating, if not challenging the original written Torah). If we accept the way in which texts themselves date this process, then it lasted more than a millennium and a half. ${ }^{29}$ If we prefer instead to adopt any of the most diffused versions of the Documentary Hypothesis, this period should be halved but is still very long, still much longer than the duration of the entire classical Greco-Roman civilization (from Plato to Augustine). The texts of tradition claim a complete continuity from Moses to the Talmud, ${ }^{30}$ but this is

\footnotetext{
27 Yitrò for example in Es.18:23 makes reserve for an explicit divine approval of its advice.
}

28 A famous case is that of the Paschal sacrifice, Korban Pesach, which in Ex 12:1-28 seems to be only roasted lamb and in Deut 16:2 to be cooked (hence possibly boiled) beef. The chosen solution was to follow strictly the first indication and treat the latter as inclusive of other circumstances. See http://ohr.edu/explore_judaism/daf_yomi/weekly_dafootnotes/1019.

29 The life of Moses is dated back in the fourteenth century before our era; the first writing of the oral Torah, that of the Mishnah that ends in the late second century CE.

30 Thus the famous first chapter I of the Treaty "Pirkei Avot", certainly the best known of the Mishnah: "Moses received the Torah at Sinai and transmitted it to Joshua, Joshua handed it to the elderly and the elders to the prophets and the prophets to the members of the Great Assembly" etc.. Note that the verbs used for transmitted and received are Mesariá and Kibuli, from which arise two key cultural developments of Judaism for the future: the Massorà, or care of the philological texts beginning from the 


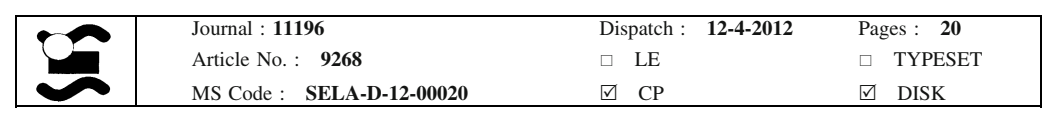

obviously an ideal claim that can not be supported by a textual evidence. ${ }^{31}$ The problem of the authorship of these "additional" texts is therefore very complex, because they present themselves in an explicit way as the sum of all this millenary work (Mishnah Pirké Avot: 1).

The most complete exposition of this comprehensive "repetition" (this is the meaning of the Mishnah) of the Torah is called Talmud (literally "study"). The Talmud is composed of two layers, the most ancient Mishnah, which was completed in the second century, and its own big commentary, the Gemarah, achieved between the sixth and the seventh century, which comes in two versions, the Babylonian one, the widest and most influent one, and the Jerusalem version, more limitated but nevertheless very authoritative. The Talmud is organized in "orders" and treaties; hence, theoretically, it features a very neat frame structure. It also specifies in detail and through cases the Jewish rules, and therefore it is the most comprehensive and authoritative expression of the Law. But its composition is extremely complex, particularly in terms of authorship.

The Mishnah plainly shows the intent to be a sort of code, a systematic presentation of the Jewish law, but in fact presents itself sometimes also as a sort of ideal record of the discussions of the early pharisaical masters, the so-called Tannaim. This record is ideal because the opinions of authors even centuries away from each other are juxtaposed and contrasted, so that the discussion is virtual, not real. In the Mishnah there are also anonymous voices, included a distinct discursive position that can close the discussion with binding conclusions (but not always does), and one finds also different kind of materials as narrative interludes, quotations from other parallel sources. All this in a rather terse and simple style. The Gemarah works more or less the same way, but it shows the general form of a discussion and not that of a code and has a far stronger emphasis on the different opinions, including many quotations from different sources and large narrative interpolations and speculative discussions, usually called Haggadot. The arguing masters are often of later époque, dating back until to the sixth century. The discussions start always from the arguments of one point of the Mishnah, complete and comment them, try and clarify the doubts, add more or less pertinent considerations and associated themes. Sometimes some recent opinion contradicts

\section{Footnote 30 continued}

seventh century, and the Kabbalah, the mystical movement that defines itself as the guardian of the secret tradition of the Torah. The received Torah, in the opinion of commentators, "are the written and oral ones." See Mello (ed.) [11] ad loc. which shows the classical commentaries.

31 The prophets, who at least in terms of the text self dating are intermediate between the Torah and Talmud, often emphasize the adherence to the law of Moses, but then sometimes speak as if they did not know it. See, as examples, the discrepancy between the description of the shrine of Ezekiel and that of the Exodus or the polemic against the sacrifices prescribed in Leviticus by Amos 5:21-24 ("If you offer me burnt offerings and grain offerings, I do not like: the fat of your sacrifices of fat victims I do not even look"), Isaiah 1.11-12 ("I am enough of burnt offerings of rams and the fat of the calve, I do not like the blood of oxen, lambs and goats. When you come to appear before me, who will claim this from you?"), Jeremiah 7.22 ("In truth, I did not speak, nor gave I command to your fathers about the Holocaust and the sacrifice when I brought them out of Egypt) etc. The controversy, however, certainly revolves more on the "hypocrisy of the rituals" as they were then realized in that time, that it does against the sacrifices as such in principle. 


\begin{tabular}{|l|lll|}
\hline & Journal : 11196 & Dispatch : $\mathbf{1 2 - 4 - 2 0 1 2}$ & Pages : $\mathbf{2 0}$ \\
& Article No. : 9268 & $\square$ LE & $\square$ TYPESET \\
MS Code : SELA-D-12-00020 & $\square \quad \mathrm{CP}$ & $\square$ DISK \\
\hline
\end{tabular}

The Author of Halakhah?

451 the Mishnah conclusions (but always on behalf of other Tannaim, whose opinions 452 missing from the discussed Mishnah text are presented in other sections or in other 453 collections called Toseftah, which means "Supplements", or in Baraitot, i.e. "added" 454 texts that we know through their quotes). Complex and labyrinthine, often written with abbreviations and ellipses, with many diversions and often lacking of precise conclusions, the text of the Talmud is very long and sometimes very difficult to understand. Often a discussion can be concluded with a final binding opinion of the anonymous editor. Otherwise the various opinions displayed are later assessed according to the authority of the author to which the judgment is attributed, as to his époque and to the school to which he belongs, and of course according to the judgment of the other sages on such opinion. ${ }^{32}$

What one among different Talmudic opinions is actually Halakhah, was decided in practice many centuries later by a number of real codes that have been composed over the time on the ground of these discussions and their subsequent comments. ${ }^{33}$ The most authoritative codes, which don't quote the discussions, but refer only the corroborated conclusions, are the Mishnè Torah of Maimonides (twelfth century) and the Shulchan Aruch of rav Caro (sixtieth century), which is used until now. These codes also underwent the process of endless commentary that is so characteristic of Jewish thought, even of the legal one: only through the commentary (i.e. referring to previous statements), the chiddush (innovation) is legitimate. But conversely the comment is also intended as the cultural device needed to introduce this ceaseless innovation, without which the law would not make sense in a changing world: a dialectic of conservation and change that is an extraordinarily rich and complex and even formalized model of the meaning of tradition.

It is worth noting at this point that although the great codifications are considered as established and is universally shared in the Jewish world, the process of interpretation/innovation/legislation continues today through the practice of responsa or Theshuvot, which were utilized for the first time in the Babylonian period, more than fifteen centuries ago. The rabbis may assume the authority of poséq, decision makers, and as such take the responsibility of applying the principles of written and oral Torah to more or less new concrete situations. Any new opinion may of course be contradicted by others rabbis and often it is and a new discussion starts. But in principle, sooner or later, a consensus is formed and a decision taken. It is worth noting that usually the memory of minority views is preserved in these discussions as it happens always in the Talmud. The Jewish law is evolved this way, through decisions concerning practical cases and not by means of legislative acts or abstract conceptualizations (and, therefore, it is closer to the common law than to the Roman law) and on the basis of expert consensus, based on previous decisions (or older minority opinions), by extending or redefining them. There is, thus, a continuity of law that affects many rules (there are no other examples which I know of, of laws made twenty or thirty centuries ago and

\footnotetext{
$\overline{32}$ For a more precise explanation of this structure, cf. the texts of Steisnatz [19], Steinberger [20] already mentioned and Sierra [18], Ouaknine [14], Avanzinelli [4].

${ }^{33}$ Also in this case the comments of Rashi and those of his immediate successors, the Tossafot, should be mentioned as particularly influential.
} 


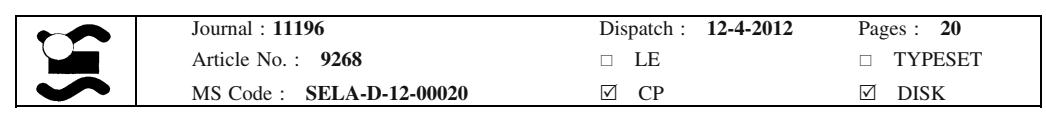

continuously applied until now, as happens for example in the Jewish marriage law, which is subsumed in the Israeli legal system; or, in particularly observant communities, also in the economic and family law.

The basic idea is, however, that the law emerges from the discussions of the sages, through dialectical and very complex processes (Lampel [8]), and that the strength of tradition consists especially in this exchange of views, which is worthy in itself. The authorship of the law in this stage, is necessarily a collective one. The consensus of the sages, more than the single poséq shapes the law. A famous passage of the Talmudic treaty Eruvim (13b) maintains that:

A debate between the schools of Hillel and Shammai lasted three years. They insisted that the [application of the] Torah was to be established in their opinion, and they insisted that the [application of the] Torah was to be determined in accordance with theirs. Finally, a heavenly voice rang out: "The views of both these and those are the words of the living God! However, the [application of the] Torah must be determined in accordance with the provisions of the school of Hillel."

Therefore, in the end, the debate comes down to a practical decision, but all opinions are "words of the living God," even those who are refused, need to be preserved: this is the reason why the Talmud is shaped more as a minute than of as a code. ${ }^{34}$ About the Talmud, there are explicit meta-rules in order to determine, from the record, which opinion is the legally binding one, the one that gives rise to Halakhah: for instance, the just quoted one states that in every discussion among the two great legal schools of Hillel and Shammai, it is always the first to prevail, except for a small number of specifically stated exceptions. Another important criterion is the prevalence of the majority of the sages of the generation against any dissenting opinion, but authoritative, that was already mentioned in a previous note. The typical case in which this rule applies against an influential rabbi and even against the apparent will of God is the case of "the Akhnai oven"35:

If a man made an oven out of separate coils [of clay, one upon Placing Another], then put sand Between Each of the coils-such an oven, A. Declared Eliezer, is not susceptible to defilement, while the sages Declared it susceptible. It is Taught: On That Day R. Brought forward Eliezer Every imaginable argument, But The Sages did not accept any of Them. Finally He Said to Them: "If the Halakhah (religious law) is in Accordance with me, let this Carob tree test it!" Sure enough the Carob tree uprooted Immediately Moved Itself and one hundred cubits, and Some say 400 cubits, from the ITS place. "No proof can be Brought in from Carob tree," they retorted.

And again He Said to them "If the Halakhah agrees with me, let the channel of water testing it!" Sure enough, the channel of water flowed backward. "No

\footnotetext{
34 It is an interesting fact, and certainly an unusual one in the history of religions that the Talmud preserved also the views of Elisha ben Abuya, who is accused by the Talmud of apostasy and hence was nicknamed "acher" (meaning "the other") because of his "epicurean" views.

35 Talmud b. Baba Metz 59b, see Rabello [15]: 49.
} 


\begin{tabular}{|l|lll|}
\hline & Journal : 11196 & Dispatch : $\mathbf{1 2 - 4 - 2 0 1 2}$ & Pages : 20 \\
& Article No. : 9268 & $\square$ LE & $\square$ TYPESET \\
MS Code : SELA-D-12-00020 & $\square$ CP & $\square$ DISK \\
\hline
\end{tabular}

The Author of Halakhah?

proof can be Brought from a channel of water," they rejoined. Again he urged, "If the Halakhah agrees with me, let the walls of the house of study testing it!" Sure enough, the walls tilted as if to fall. But R. Joshua, rebuked the walls, Saying, "When disciples of the wise are Engaged in a halakhic dispute, what right have you to Interfere?" Hence in deference to R. Joshua They did not fall and in deference to R. Eliezer They did not resume Their upright position; They are still standing aslant. Again R. Eliezer then Said to the Sages, "If the Halakhah agrees with me, let it be Proved from heaven." Sure enough, a divine voice cried out, "Why do you dispute with R. Eliezer, always agrees with Whom the Halakhah?" R. Joshua Stood up and protested: "The Torah is not in heaven!" (Deut. 30:12). We pay no attention to a divine voice long ago at Mount Sinai Because You wrote in your Torah at Mount Sinai, 'After the majority must one incline'. (Ex. 23:2) "R. Nathan met [the prophet] Elijah and asked HIM," What did the Holy One do at That Moment? "Elijah," $\mathrm{He}$ Laughed [with joy], Saying, "My children haves defeated Me, My Children Have defeated Me'".

Both biblical quotations in this Talmudic discussion are very constrained. The verse in Deuteronomy, literally read, means that the Torah can and must be applied by the Jews in their daily life, while the one from Exodus orders more or less the opposite of what is told here, since it clearly says "do not you join a majority to make the evil" (which is itself ambiguous: see Rashi [17] ad loc.). And yet this strange assembly of text expresses a deep belief that has shaped all Judaism from that time on, perhaps for polemic reasons with Christianity and other alleged messiahs of that time, as the study just mentioned says: with the closure of the Biblical canon, the time of prophecy ends for the Jewish world and the hermeneutic thought predominates. Rabbinic Judaism of the last twenty centuries bases its legislative work on comment, on rational debate and on the consensus of the scholars of a given generation. That is very important for our problem, because in some way the divine authorship itself is considered as "closed" or no more productive. For the Jewish thought God of course is always the legislator of the Torah, but at a certain point He Himself ruled out His authorship, or maybe every real legislative authorship. Now only comments are admissible, and in this field the form of production is discussion and the necessary criterion of it is consensus.

This is also a reason why the Talmudic law has the form of minutes of all the relevant views expressed, in order to enable the masters of a later generation to overturn the choice of previous ones, by relying on the opinion of some minority of the past.

And why the opinion of the individual is remembered, alongside with that of the majority, since the Halakhah cannot conform but to the majority? Because if a court in the future will repute the opinion of the individual as plausible, it will be able to use it as support. ${ }^{36}$

36 Mishnah Eduiot 1: 5. See Rabello [15]: 27. Note that this willingness to overturn in the future a rule (or rather a rabbinic court decision) even providing the tools for making it possible the reversal, is one of the great difference between the Jewish and Islamic legal system, which also show similarities formal being grounded both on a sacred text and an interpretive/legislative work around it. Except that for almost 800 years the Islamic legal system has been "locked", when in 1258, with the Mongol conquest of 


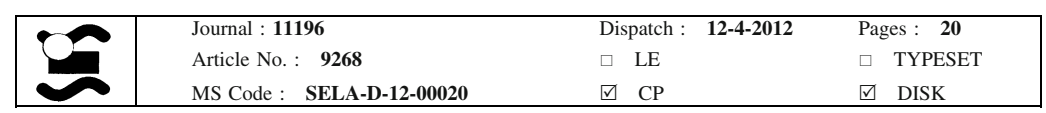

Given this structure, in which the code is used not only to expose rules, but also reasons and objections and alternatives, with their own reasons-and that about every single detail-, it is clear that the Talmud is a very crowded text and at times a truly labyrinthine one. Moreover, given the fact that it is based on oral traditions that account about all these views for centuries long; and since there is also a good rate of homonymy between the teachers mentioned, there is often confusion about the actual authors of a single position ${ }^{37}$ and the risk of getting lost is high. But in fact, if not the motivations and objections, at least the final decisions, when they are expressed, are quite clear. We must also add that the secular activities of commentary has elaborated the current text of the Talmud as a kind of hypertext, ${ }^{38}$ where the internal references, the different positions and the difficulties are mentioned and possibly resolved, so that gradually the Talmud (or its anonymous editors) was thought of as a sort of super-author able to organize the debate in such an order that leads to the right conclusion.

In fact, after the great task of medieval and early-modern codes, the Talmud is no usually not managed with a direct reference to it, but mainly as a privileged object of study and a source of inspiration for the new problems that arise. It is therefore today a repository of principles, knowledge, intelligence, an anchoring point, rather than a code.

Finally, we must add that a well established hierarchy organizes this complex structure of rules: there are min hashamaim rules (literally "from heaven", of divine origin, also called miSinai, given at Sinai, or in Aramaic mideOraita, from the Torah), a concept generally very extensive and hence object of many discussions. ${ }^{39}$ Then there are rabbinical (derabbanan) rules whose rationale is "to make a fence around the Torah" (Pirkei Avot 1:1), i.e., to prevent involuntary breaches by adding extensive rules and precautions (for instance the prohibition to perform certain acts although prescribed by the ritual of certain festival — such as playing the ram's horn for Rosh Hashanah - when the festival falls on a Saturday, so as to prevent that someone would want to carry the instrument from home to the synagogue, which is forbidden by the rules of Shabbat) or to address situations not covered by the old legislation. ${ }^{40}$ Finally, there are customs and traditions of some places or even

Baghdad was closed the so called "door effort": the four legal schools (madhhab: Hanafi, Malic, Hanbali, Shaifi'it), have been fixed for ever, ancient decisions can not be discussed more. 37 See for example the passage, by no means atypical, of the Treaty of Moed Katan 22a.

38 The standard layout itself of the Talmud presents an hypertextual form, with the passage of the Talmud in the middle of every page and all around, with different bodies and characters, the main comments (Rashi, Tossefot etc.) the links to parallel passages, the notes of later authorities (Gaon of Vilna, etc.) and so on. For an explanation see Ouaknine 1986. The theme of the argumentative techniques of the Talmud (for instance, the thirteen principles of interpretation that are stated and applied in the Talmud, the discursive form in which its "ideological grasp of the world" takes place, its very idiosyncratic way of thinking and discussing) goes beyond the limits of this essay. the future will say "deducing it from the Law" (Palestinian Talmud, treated Pea, 2,4,17 a). See Volli [24].

${ }^{40}$ Given the very extensive definition of the "divine" law, which includes also what is inferable in a more or less logical way from other divine laws, the distinction between "de oraita" and "de rabbanan" laws is 


\begin{tabular}{|l|lll|}
\hline & Journal : 11196 & Dispatch : 12-4-2012 & Pages : 20 \\
& Article No. : 9268 & $\square$ LE & $\square$ TYPESET \\
MS Code : SELA-D-12-00020 & $\square$ CP & $\square$ DISK \\
\hline
\end{tabular}

The Author of Halakhah?

602 broader geographical traditions (minhag hamakom), which are obligatory for the 603 Jews of that place but not for others.

604 The rules of authorship, of course, depend on this hierarchy: the first kind of laws 605 require a biblical reference, although it can be sometimes not so evident; the second ones are formulated by some precise master, must always be supported through reference to earlier rabbinical authorities, perhaps by means of analogy, but are actually established by a rabbinical consensus; the third ones, often without known author rest only on the witness of an established use. This last kind of norms recalls the fact that in the Jewish tradition the popular habit are a recognized source of law, although a lower one.

At this point, we can draw some provisional conclusion. The Jewish legal tradition is remarkable for its antiquity and complexity, but also for the articulation of its authorship. On the one hand, the centrality of divine unity in the Hebrew concept of God is reflected on the intuition of one single divine law in some way older than the whole world and anyway somehow all already given in the Revelation of Sinai. Moreover: the strong sense of divine "regality" as the only possible source of power implies that only the rule of God is real law. The kings of Israel have certainly established rules, but these do not become part of the "real" law. At most they can help, for instance rediscovering a lost text, as 2 Kings 22-23 say king Josiah (621 $\mathrm{BC})$ did. On the other hand, the actual structure of the legislation is highly pluralistic, as I have documented. The articulation in this apparent oxymoron is the concept of interpretation and development. But this fact should be read also as a significant case of political theology (Assmann [2, 3]; Taubés [21, 22]). That the true law can come only from the sky, means that the real ruler of Israel can only be God, not the Pharaoh of Egypt, which is the apparent target of all the biblical passages that border on the topic, but even the kings of Israel, which are processed by Mikrah with extreme distrust, not only because it is generally portrayed as sinners, but in principle the institution of the monarchy:

But when they said: "give us a king to lead us" they let Samuel regret, so he prayed to $Y-H-V-H$. And $Y-H-V-H$ said to him: "Listen to all that the people will tell you, they are not rejecting you, but they rejected me as their king." (1 Samuel 8:6-7).

This political theology expresses the opposition character under which the canon of the Bible was formed: Moses's opposition to the Pharaoh, prophets' opposition to the kings, the Pharisees' opposition to the clergy of the temple, the Jewish opposition to the cultures of exile. This led to enhance the role of intellectuals (the rabbis) and to see the law as something whose author is certainly divine, but that is 


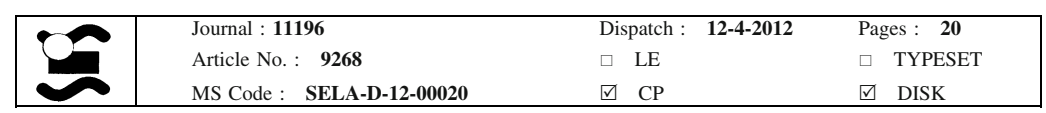

entrusted to their hands and their responsibility. This is the meaning of the story of the Akhnay oven we have mentioned before.

From a theological perspective, the first goal for a Jewish theory of the law authorship is to ensure the transcendence of this Author, against all temptation of his incarnation. This is the reason for seeing the text of the law as something concluded, given once and for all, in terms of the Hebrew theory of the language as a davàr (word issued and fixed as a text, i.e. unchangeable) more than as amirah (a dynamic speech, a spoken discourse). On the other hand it always has been necessary to ensure that the system keeps its its dynamism and can adapt to a historical-political situation of continuous change in which, to quote Heine, for two millennia the law was intended to be the only "portable homeland of the Jewish people". Only in this way, articulating its fundamental unity with a plurality that is sensitive to the passing of time, it may continue to be consistent with its name: Halacha, the path.

\section{References}

1. Askènazi, Lèon. 1999. La parole et l'ècrit I. Paris: Albin Michel.

2. Assman, Jan. 1992. Das kulturelle Gedaechnis. Muenchen: Oskar Beck.

3. Assman, Jan. 2000. Herrshaft und Heil. Muenchen: Carl Hanser.

4. Avanzinelli, Milka Ventura. 2004. Fare le orecchie alla Torah. Firenze: Giuntina.

5. Banon, David. 1987. La Lecture infinie-les voies de l'interprétation midrachique. Paris: Seuil.

6. Cassuto, Umberto. 2006. The documentary hypothesis. Yerushalaim: Shalem Press.

7. Genette, Gérard. 1972. Figures III. Paris: Seuil.

8. Lampel, Zvi. 1992. The dinamics of dispute. New York: Judaica press.

9. Lévinas, Emmanuel. 1982. Quatre lectures talmudiques. Paris: Minuit.

10. Lévinas, Emmanuel. 1996. Nouvelles lectures talmudiques. Paris: Minuit.

11. Mello, Alberto (ed.). 1993. Detti di rabbini, Bose Qiqayon.

12. Maimonides Moshe (Rambam). 2002. Le 613 mitzvot, Milano: Mosé Levi.

13. Ernest, Nicholson. 1998. The Pentateuch in the twentieth century. Oxford: Oxford University Press.

14. Ouaknine, Marc-Alan. 1986. Le livre brulé-Lire le Talmud. Paris: Lieu Commun.

15. Rabello, Alfredo.Mordechai. 2002. Introduzione al diritto ebraico. Torino: Giappichelli.

16. Rashi, F. 1985. Commento alla Genesi. Genova: Marietti.

17. Rashi, F. 1988. Commento all'Esodo. Genova: Marietti.

18. Sierra, Sergio (ed.). 1995. La lettura ebraica delle Scritture. Bologna: Edb.

19. Steinsaltz, Adin. 1977. Ha-Talmùd lakol. Yerushalaim.

20. Stemberger, Guenter. 1982. Der Talmud. Munchen: C.H.Beck.

21. Taubes, Jakob. 1983. Der Fürst dieser Welt. München: Fink.

22. Taubes, Jakob. 2003. Die politische Theologie des Paulus. München: Fink.

23. Volli, Ugo. 2008a. Al principio-interpretazione oltre l'interpretazione-Un esempio ebraico. $V S$ $103-105$.

24. Volli, Ugo. 2008b. Separazione e rivelazione-I nomi del santo in Sefer Shemot. In Destini del sacro -Discorso religiose e semiotica della cultura, eds. Nicola Dusi e Gianfranco Marrone, Roma: Meltemi.

25. Volli, Ugo. 2010. ¿Qué cosa es un libro para el Libro de los libros?. Tópicos Del Seminario 22.

26. Volli, Ugo. 2011. Previsione, profezia, senso. Lexia 7-8. 